\title{
The Values of Virtual Civilization in the Times of Global Consumption: Homo Sapiens VS Worldwide Pandemic
}

\author{
Elena Pavlova ${ }^{1 *}$ \\ ${ }^{1}$ Rostov State University of Economics (RSUE), Faculty of trade, Rostov-na-Donu, Russia.
}

\begin{abstract}
.
Research background: The article is devoted to the phenomenon of COVID-19 and its influence of modern man. The article analyses the processes in which the mechanisms of human interaction with the environment manifest themselves, as well as ways to address the destructive processes in the minds and behavior of modern man.

Purpose of the article: In this article, from the point of view of philosophy, one of the most complex phenomena of the modern information age, is characterized, namely the modern stage of the human society in the context of pandemic is studied and analyzed.

Methods: Theoretical interpretation of understanding of problem of interpersonal communication in the context of globalization and pandemic COVID-19 requires an integrated approach. The method of temporal analysis and the method of personalistic and ideal-typical reconstruction, a tool that is adequate to the author's interpretation of social self-organization in the era of globalization as a process of constituting the temporal and ethical dominance of individuals and collectivities that formalize the integrity of the cultural epoch, will become the immediate, applied methodological basis.

Findings \&; Value added: Summing up our reflections, we can say that it is the flexibility, multiple variability in different behavioral situations tha is often the key to successful and efficient activity. On the contrary: constriction, resistance to the changing conditions and factors very often become an obstacle on the way to successful communication with the world around us.
\end{abstract}

Key words: globalization, pandemic, crisis, consumerism, person, relationship, communication

JEL Classification: $D 83, F 01, I 18$

\section{Introduction}

${ }^{*}$ Corresponding author: pavlova@philosophical.ru 
The inhabitants of the Chinese city of Wuhan, which is located in the center of the country, could barely have imagined way back in remote 2019 (for too many things have happened in the world since that time), that their city would go down in the world history as the starting point of the global pandemic of the coronavirus disease (COVID-19), as the city that irreversibly changed the world economy, politics and culture.

In our view, the most interesting thing is that until now, humanity in its overwhelming majority has not yet realized a simple fact that the world has changed utterly and irrevocably. Certain behavioral strategies and tendencies of social development have sunk into oblivion Gadzhiev and Voinikanis (2021). Again (one more time), humanity is facing the problem of working out new worldview landmarks, values and norms.

Our paper is dedicated to the Covid-19 pandemic, and, more pointedly, to its consequences and influence on interpersonal communication and consumption, as well as to the investigation of this phenomenon from the «pro et contra» point of view.

On the example of an extensive historical, philosophical and sociocultural discourse, the main milestones in the transformation of human understanding and attitude to the basic existentials of their being are shown. The main emphasis of the article is made on the study and new reception of some previous views on the phenomenon of the subjective reality of the individual and the role of television culture in its formation Smilansky (2021). Shown are the main points that can help a person to return to their integrity and lack of split consciousness.

\section{Methodology}

The theoretical interpretation of the transformation of human social activity in the context of globalization requires an integrated approach.

The methodological basis for this article will be:

- system-activity approach, according to which knowledge acquires value only when it is included in the practical activity of a person; Smolin (2021)

- an individual approach, involving the development of a personality through the organization of its activities; Liu and Zhu (2021)

-integrative approach, which determines the consistency and integrity of education, the integrative essence of the personality of a modern person Laimann (2020).

The method of temporal analysis and the method of personalistic and ideal-typical reconstruction, a tool adequate to the author's interpretation of social activity of a modern man in the era of globalization as a process of constituting the temporary and ethical domination of individuals and collectives that formalize the integrity of the cultural era, will become a direct applied methodological base.

\section{Results}

\subsection{COVID - 19: A Deafening Influence on Human Civilization}

We believe that the current pandemic situation illuminates one of the many problems of humankind has today, namely, the catastrophic lack of empirical experience and personal live communication. Having found ourselves locked in our own homes, we acutely realized the genial prophecy of J. Brodsky's words: «Make that wardrobe a barricade. The fates require us to keep out Cosmos, Chronos, Eros, Race and Virus!» 
We don't see our neighbor, our friend, our student, our teacher. Our outlook is limited to the blinking screen of our personal computer, where each of us, depending upon our experience, personal preferences and life-purpose coordinates, is looking for and constructing our own view of reality.

It is true, that many of us have to acknowledge bitterly that interesting and horizonsbroadening trips to other countries are decreasing, and the world, which used to be entirely open for travelling, is consistently shrinking like Balzac's "The Magic Skin», to be captured only on the blue screen of the monitor in the well-known Google Maps sometimes.

It is true, that we are becoming more and more scared to get together as a big group of friends; we now prefer to walk alone or communicate with the closest people only.

It is true, that economy of many countries, which had been living off a continued influx of tourists, collapsed, leaving a huge number of people on the verge of survival, unemployment and stagnation.

The spring and summer of 2020 became distinctive time markers, a certain acid test, which distinctly highlighted irreversible changes in the global civilization and culture more than ever before.

However, we are strongly convinced that this acid test showed something different. In our view, the key problems of the modern «COVID-19» civilization began to emerge before the coronavirus pandemic. One of these problems was characterized in scientific and public literature as «technological fetishism».

\subsection{A Technical fetishism as a marker of social processes in a society of the consumption}

For example, some modern Russian politologists point out: «The peculiarity of modern technological fetishism lies in the fact that the object of fetishization is a technical device, which is created as a result of human intellectual activity. It's one thing when military weapons become a fetish, but it's quite a different thing when we speak about a mobile phone, which is lying peacefully in our pocket, connecting us with close and important people Kozyrkov at al. (2019).

Thus, the bridge Giordano Bruno was dreaming to build across a terrifying abyss is carried in the pocket of the modern man: it is a bridge connecting people with one another. However, no mobile phone can connect people with each other if this connection does not exist in its live, sociocultural form. Instead of live interaction, according to Plato, we'll get only a «made-up toy» of a «made-up human».

Let's consider this. The abovementioned quote was taken from the 2016 paper. It was published three years before the global pandemic.

Another example is the American philosopher of the 20th century Erich Fromm, who said in his famous interview with Mike Wallace on ABC channel (May 25th, 1958), that the modern western American society, while promoting and protecting human freedom in all its senses and aspects, has, in fact, turned into a society of democratic, moderate liberal captivity, and its people, who recently advocated for exceptionalism of an individual, have turned into consumers, focusing their attention on purchasing a new car or a house as a symbol of human happiness and the essence of the American dream. Those were ideas of democratic unfreedom and total consumerism. 
It was said in 1958. Sixty years before the global pandemic and its first economic and political consequences.

We believe that it is the attitude towards the consumption process and its transformation under COVID-19 that constitutes the essence of human civilization today.

Let us remember that the term «consumption» gained its greatest popularity in the mid-twentieth century after the Second World War, and it is attributed to the names of wellknown philosophers: J. Baudrillard, H. Marcuse, E. Fromm.

This term, which entered the global culture in the mid-twentieth century, is a phenomenon, distinctly outlined in the works by the famous American philosopher Erich Fromm, who negatively perceived the fundamental changes in the attitudes of AmericanEuropean society in the post-war civilization space.

Very often, it is a tag convenient to label social processes taking place in the modern world and to attribute the global crisis to the irresistible desire of a certain amount of people to rule, accumulating something (money, resources, power, weight) in our universe Gallow (2021).

Today, the set phrase "consumer society» is a cultural meme, a socio-cognitive pattern, well-established in modern people's minds with a negative connotation in most cases.

«To consume» means to be in hot pursuit of material things, to become a slave of «commodity fetishism», according to Karl Marx, to lose one's individuality, joining the straight ranks of consumerists Marx and Engels (1962). Today, consumption means loss of personal integrity, materialism, massive involvement, general dumbing-down.

The affluence of the world around us is the affluence of someone else's interests, the interests which fling onto us almost from the moment of our birth. Before we have enough time to mature as a person, we begin to make sense of the endless extensively advertised gadgets, being moved and overwhelmed by the «forward-minded» toddlers, who knowingly, in a business-like manner, accurately press the necessary buttons in their mother's smartphone or a tablet, which was presented by their loving grandmother, to play a cartoon.

Following the idea of the French philosopher of the last half of the 20th century Albert Camus, who once said that we get into the habit of living before acquiring the habit of thinking, we would like to add that the system of values, which is evolving during our whole life, usually develops outside and without our conscious engagement.

As children, we blindly copy the manner of behavior and attitude to other people based on our observations of the closest adults, who come to our attention, namely our parents.

As teenagers, we acquire new idols -actors, singers, writers; so, we copy our favorite actor's tone of voice or our adorable singer's sullen look.

In other words, a person's system of values begins to establish almost from the cradle. In many aspects, it is the system of people's values that lies at the heart of their worldview, i.e. the way they see the world and their place in this world, the way they understand their opportunities and how to turn these opportunities into reality Preston G. at al. (2019). Having a certain worldview, a person sees the world in its unique distinctiveness, which no one else can see; this kind of distinctiveness determines the uniqueness and individuality, as well as constant versatility of this person Kieran (2020). 
But who is responsible for the way I see the world, which of its facets will form my self-perception, embedding either openness and total trust to the world or anxiety and a wish to isolate myself in my inner hiding place from all the dangers awaiting me outside; who is shaping my personal focus on owning things, on willingness to gain as many things as possible, on the unstoppable desire to possess more and more?

\subsection{The role of television in a shaping of the worldview of a modern person: risks and prospects}

In our point of view, the answer is obvious. Since the 1930s a phenomenon entered every person's life without which modern culture and civilization could not become what they are.

Let us not arouse the curiosity of our readers for too long. What we mean is television. For instance, the first trial broadcasting session in the Soviet Union took place on the 29th of April 1931. The first television broadcasting center was opened on Shabolovka Street in 1937; it started experimental electronic-system broadcasting in 1938, and regular broadcasting began in 1939 (the first program being a film about the opening of the 18th Congress of the All-Union Communist Party of Bolsheviks).

It's almost impossible to imagine a modern person who doesn't use one or another system of electronic communication with the outside world. It is true, that «the television human», «the virtual reality human» is spoiled by the fact that he finds himself in the information cocoon: without any opportunity to experience actual conditions, he can observe virtual conditions, he doesn't see what surrounds him, but he sees what is shown to him Smortchkova (2020).

Our «Self» receives strictly apportioned, rigidly structured information with certain schemes and symbols always hidden inside at some subconscious level to form our overall attitude towards the viewed content Chilvers and Kearnes (2020). This is similar to a barely noticeable beacon, which lights up in my mind not to let me stray from the correct path.

For example, if I am shown how someone cuts wood, carries hay on the back, grows chickens, or weeds the garden, the emphasis is placed on how hard this kind of work is, and how unbearable the working conditions are. So, we feel pity for Tibetan women carrying $100 \mathrm{~kg}$ bundles of hay, sympathize with African people's weather-beaten faces, quietly dismayed by the inhuman insanitary conditions they have to endure.

However, at the same time, if I only press one tiny button on the TV remote, I can switch to a program about ultramodern houses, where devices programmed by the leading world engineers are turned on and off, and food, clothes, and services are delivered right to my place Schwarz W. (2021).

Gradually, I become a slave to consumption, like a hamster in a wheel all I can do is run. I live and I work only to buy a new suite of furniture, I save up for a two-week holiday, and I dream about a new IPhone $11,12,13 \ldots$

As a result, my freedom starts to be associated with the level of consumption I can (or can't) afford. Poor Socrates once strode through the central marketplace in Athens and noticed to himself: «How many things I don't need!» But he couldn't even guess how gigantic the amount of goods and services will be, which his remote descendants can't imagine their lives without.

The modern television human proudly speaks about the latest scientific advancements and... dreams about a new suite of furniture from IKEA, speculates about the benefits of a 
healthy diet and... buys sausages and cakes stuffed with a huge amount of phosphates and preservatives for holiday feasts, saves up money for a two-week holiday when all he is going to see will be just a painted picture shown to him from the window of a tour bus or an accurately marked out beach restricted from the real life, and consumes, consumes, consumes.

We are constantly looking at the carrot dangling in front of our nose, and, being enchanted by the sight of this carrot (which we have to manage to get), we do not notice the things around us. There may be a star at one side, but just like the enchanted wicked witch from the «Stardust» film, we cannot see the star, we cannot understand that it is our greatest treasure in life, the one we have been looking for. We are still looking at the carrot.

In our view, the first global religion, Buddhism, brilliantly showed the essence of human consciousness and human subjectiveness in general. In Buddhism, our subjectiveness is represented as nothing but a monkey jumping randomly and chaotically on the numerous branches of a huge tree. These branches can symbolize any aspect of our reality, which we stick to for a certain moment in our samsaric existence, which attracts our attention and where our interests are focused. The more branches, the harder for the monkey to stay in one place - for it has to try and jump onto another branch, and then another, and another branch is also worth visiting.

But what if we try to cut off the unnecessary? While throwing away unnecessary branches, the monkey starts to focus its attention on those branches which cannot be thrown away.

In other words, creating a vacuum, putting off the moment of making a decision, escaping unnecessary impressions, we get a chance to watch the real world around us. That means, by constant filtering out events happening around us, reducing diversity of life, our consciousness stops jumping from one external factor to another. Gradually, we begin to understand what the most important thing really is. And the greatest luxury is the luxury of real human interaction. Antoine de Saint-Exupéry has been right for almost eighty years.

\section{Discussion}

The work adjoins the main thematic areas developed within the domestic and foreign schools dealing with the phenomenon of social and economical crisis in modern society and is the result of many years of the author's work on the problems of theory, practice and methodology of socio-philosophical problems of culture and society.

The discussion nature of the work is related to the specifics of its object, object and purpose and is determined by the nature of its tasks. The work is aimed at systematization, deepening and refining of modern philosophical knowledge about the essence of social crisis in modern Russia and in the modern world on the whole in the conditions of globalization.

\section{Conclusion}

We believe that one of the primary goals of the modern philosophy is the search for the new world outlook model, a model that will help us to form the new relation to ourselves, other people and the world around us.

I believe that the American writer Michael Crichton in his book «Jurassic Park» once observed a very interesting peculiarity which characterizes the modern world. Let the author speak for himself. 
«What advances»? Malcolm said irritably. «The number of hours women devote to housework has not changed since 1930, despite all the advances. All the vacuum cleaners, washer-dryers, trash compactors, garbage disposals, wash-and-wear fabrics... Why does it still take as long to clean the house as it did in 1930»?

Ellie said nothing.

«Because there haven't been any advances» Malcolm said. «Not really. Thirty thousand years ago, when men were doing cave paintings at Lascaux, they worked twenty hours a week to provide themselves with food and shelter and clothing. The rest of the time, they could play, or sleep, or do whatever they wanted. And they lived in a natural world, with clean air, clean water, beautiful trees and sunsets. Think about it. Twenty hours a week. Thirty thousand years ago».

We have to emphasize, that our society is constantly self-improving. It happens so because there are some defects in the society that prevent people from living comfortably. The society, socialization are the most necessary things in life of any person. But development of a society occurs today without direct participation of people. Neither progress nor a developing society depend on a separate person. However, society progress is obvious - the state, ideologies, process of welfare Shoemaker (2016).

Yes, our knowledge is imperfect and one cannot square the circle. But the man would not be the man if he didn't aspire to the impossible. To learn and understand the unknown, to improve the knowledge are the goals for which one should live and which presence distinguishes us from animals Lvov (2020).

Summing up our reflections, we can say that it is the flexibility, multiple variability in different behavioral situations that is often the key to successful and efficient activity. On the contrary: constriction, resistance to the changing conditions and factors very often become an obstacle on the way to successful communication with the world around us.

\section{References}

1. Gadis A. Gadzhiev, Elena A. Voinikanis (2021). Balancing of Values and the Value of Balancing (Part One). Voprosy Filosofii, 9, 13-24.

2. Smilansky S. (2021). Contribution, Replaceability and the Meaning of Our Lives Theoria. https://onlinelibrary.wiley.com/doi/10.1111/theo.12352

3. Smolin O. (2021). The New Role of Knowledge in Process of Movement to Noonomy Reflection on the book Noonomy: Trajectory of Global Transformation by Sergei D. Bodrunov. Voprosy Filosofii, 9, 5-12.

4. Liu M., Zhu L. (2021). The Role of Relational Goals in Explicating Dyadic Emotional Communication Processes in Dispute Resolution: A Cross-Cultural Investigation. Communication Research, 48 (7), 1008-1032.

5. Laimann J. (2020). Capricious Kinds. The British Journal for the Philosophy of Science, 71 (3). https://www.journals.uchicago.edu/doi/full/10.1093/bjps/axy024

6. Kozyrkov, Vladimir P., Svadbina, Tatiana V., Nemova, O. (2019). Attributive qualities of personhood in the revolution of technosphere. Vestnik of St Petersburg University, 2, 23-30.

7. J. Dmitri Gallow (2021). Riches and Rationality. Australasian Journal of Philosophy. 99 (1), 114-129.

8. Marx K., Engels F. (1962). Collected works. 27, 695.

9. Preston G., Andrew J. Latham,K., (2019). Hedonic and Non-Hedonic Bias toward the Future. Australasian Journal of Philosophy. 99 (1), 148-163. 
10. Kieran S. (2020). Ignorance, Beneficence, and Rights. Journal of Moral Philosophy. 17 (1), 56-74.

11. Smortchkova J. (2020). Seeing Goal-Directedness: A Case for Social Perception The British Journal for the Philosophy of Science. 71 (3), https://philpapers.org/rec/SMOSGA

12. Schwarz W. (2021) Discourse, Diversity, and Free Choice. Australasian Journal of Philosophy. 99 (1), 48-67.

13. Chilvers J., Kearnes M. (2020). Remaking Participation in Science and Democracy. Science, Technology, \& Human Values. 45 (3), 347-380.

14. Shoemaker S. (2016). Self-Knowledge for Humans. Philosophical Review. 125(4), 589-592.

15. Lvov A. (2020). Anthropological turn in worldview studies: Theoretical and practical aspects. Vestnik of Saint Petersburg University. Philosophy and Conflict Studies, 36 (2), 279-290. 